\title{
Diazepam prodrug stabilizes human aminopeptidase B during lyophilization
}

Davin Rautiola ${ }^{1}$, Joel L. Updyke ${ }^{1}$, Kathryn M. Nelson²,3, and Ronald A. Siegel ${ }^{1,4, *}$

${ }^{1}$ Department of Pharmaceutics, ${ }^{2}$ Institute for Therapeutics Discovery \& Development, ${ }^{3}$ Department of Medicinal Chemistry, ${ }^{4}$ Department of Biomedical Engineering, University of Minnesota, Minneapolis, MN

\section{SUPPLEMENTAL INFORMATION}

*Corresponding Author:

Ronald A. Siegel, Sc.D.

Professor, Department of Pharmaceutics, College of Pharmacy

University of Minnesota, Minneapolis, MN 55455

Ph: (612) 624 6164, Fax: (612) 6262125

Email: siege017@umn.edu 
Table S1. Molar absorptivity temperature dependence.

\begin{tabular}{|r|c|c|}
\hline \multirow{2}{*}{$\begin{array}{c}\text { Temp } \\
\left({ }^{\circ} \mathbf{C}\right)\end{array}$} & \multicolumn{2}{|c|}{$\begin{array}{c}\text { Molar Absorptivity } \\
\left(\mu \mathbf{M}^{-1} \mathbf{c m}^{-1}\right)\end{array}$} \\
\cline { 2 - 3 } & LpNA & \multicolumn{1}{c|}{$\boldsymbol{p N A}$} \\
\hline 0 & $3.01 \mathrm{E}-05$ & 0.00948 \\
\hline 5 & $3.27 \mathrm{E}-05$ & 0.00957 \\
\hline 10 & $3.61 \mathrm{E}-05$ & 0.00964 \\
\hline 15 & $4.01 \mathrm{E}-05$ & 0.00971 \\
\hline 20 & $4.41 \mathrm{E}-05$ & 0.00977 \\
\hline 25 & $4.86 \mathrm{E}-05$ & 0.00982 \\
\hline 30 & $5.39 \mathrm{E}-05$ & 0.00986 \\
\hline 32 & $5.59 \mathrm{E}-05$ & 0.00986 \\
\hline 35 & $5.89 \mathrm{E}-05$ & 0.00987 \\
\hline 40 & $6.49 \mathrm{E}-05$ & 0.00988 \\
\hline 45 & $7.05 \mathrm{E}-05$ & 0.00986 \\
\hline
\end{tabular}

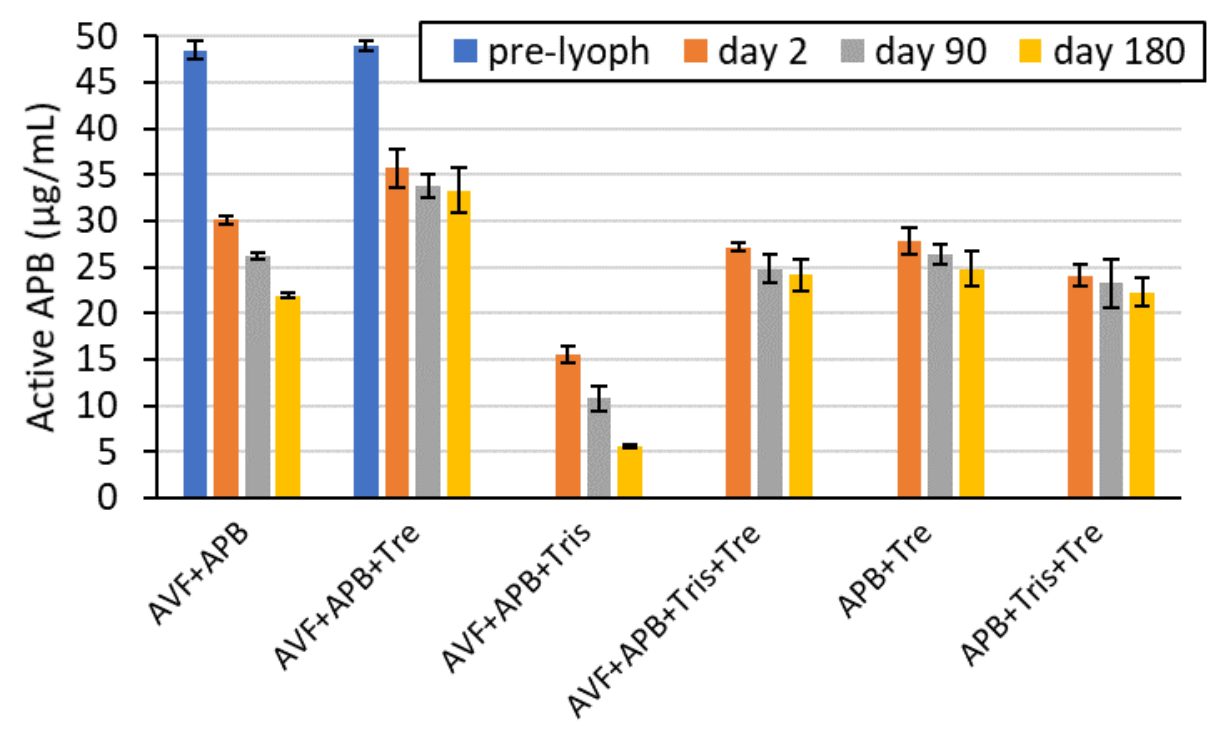

Figure S1. Lyophilizates formulations buffered with Tris. Optimum stability was achieved by colyophilization of APB $+\mathrm{AVF}+$ Tre without Tris buffer. Concentrations of active APB in the lyophilizates were measured in $\mathrm{pH} 7.4 \mathrm{PBS}$ at $32{ }^{\circ} \mathrm{C}$ after storage for the specified time at $24{ }^{\circ} \mathrm{C}$. Pre-lyophilization solutions contained AVF $=1.00 \mathrm{mM}, \mathrm{APB}=50 \mu \mathrm{g} / \mathrm{mL}$, Tre $=12.5 \mathrm{mg} / \mathrm{mL}$, and $/$ or $\mathrm{pH} 7.4$ Tris buffer $=$ $10 \mathrm{mM}$. Error bars are SD with $\mathrm{n}=3$. 